\title{
Shaping stem cell therapies in Argentina: regulation, risk management and innovation policies
}

\author{
Gabriela Bortz* \\ Achim Rosemann** (1) \\ Federico Vasen $* * *$
}

\begin{abstract}
This paper aims to analyze innovation pathways for stem cell technology in Argentina. Firstly, we present a theoretical perspective on the co-construction of regulation and technology development, positing four main tensions that underlie regulatory building and the shaping of national strategies for regenerative medicine. Regulation is understood as a negotiated process among interests, values, benefits, rewards, and different understandings of safety, efficacy, access and availability. The framework is useful to explore how actors and their visions of desired futures shape the creation of standards and, in turn, how they configure the way these emerging technologies are produced, accessed and used. Secondly, we discuss in detail the Argentine case. We focus on (a) the deployment of state actions on capacity and regulatory building, (b) the creation of new businesses in response to patient expectations, particularly umbilical cord stem cell banks and the supply of experimental treatments, and (c) state-led actions to build a specific regulatory framework (still in the making). Ambiguities and gaps in the current legislation as well as scarce enforcement capabilities configure a legal "grey area" for for-profit experimental treatments. Building a specific regulatory framework is understood to be a part of Science, Technology and Innovation (STI) state agencies' struggle to govern technology development in terms of national envisaged innovation strategies. Lastly, we show how STI authorities and scientists managed to align a broad coalition of actors that

* Universidad Nacional de Quilmes/ Consejo Nacional de Investigaciones Científicas y Técnicas (CONICET), Buenos Aires, Argentina.

** University of Exeter, Exeter, Reino Unido.

*** Universidad de Buenos Aires, Consejo Nacional de Investigaciones Científicas y Técnicas (CONICET), Buenos Aires, Argentina.
\end{abstract}


encourage international harmonization strategies, following the pharmaceutical model of drug evaluation based on the multi-phase trial system.

Keywords: Stem cells, Regenerative medicine, Science Technology and Innovation Policies, Regulation, Technology governance.

\section{La construcción de terapias con células madre en Argentina: regulación, gestión del riesgo y políticas de innovación}

\section{Resumen}

Este artículo tiene como objetivo analizar las trayectorias de innovación en terapias con células madre en Argentina. En primer lugar, presentamos una perspectiva teórica sobre la co-construcción de la regulación y del desarrollo tecnológico, y planteamos cuatro tensiones principales que subyacen a la construcción regulatoria y a la conformación de estrategias nacionales para la medicina regenerativa. La regulación es entendida como un proceso de negociación entre intereses, valores, premios, beneficios y diferentes comprensiones sobre las nociones de seguridad, eficacia, acceso y disponibilidad. El marco conceptual es útil para explorar cómo los actores y sus visiones sobre futuros deseados moldean la creación de normativas y, a su vez, cómo éstas configuran la forma en que estas tecnologías emergentes se producen, se utilizan y cómo se accede a ellas. En segundo lugar, discutimos en detalle el caso argentino. Nos centramos en (a) el despliegue de acciones estatales para la construcción de capacidades científicas e institucionales, (b) la creación de nuevos negocios en respuesta a las expectativas de los pacientes, en particular bancos para la preservación de células madre de cordón umbilical y el suministro de tratamientos experimentales, y (c) las iniciativas impulsadas por el Estado para construir un marco regulatorio específico (aún en proceso). Las ambigüedades y los vacíos en la legislación actual, así como las escasas capacidades de aplicación, configuran un "zona gris" para los tratamientos experimentales con fines de lucro. La construcción de un marco regulatorio específico es entendida como parte de la búsqueda de las agencias estatales de Ciencia, Tecnología e Innovación (CTI) de gobernar el desarrollo tecnológico en términos de estrategias nacionales de innovación deseadas. Por último, mostramos cómo las autoridades de CTI y científicos lograron alinear una amplia coalición de actores que fomentan estrategias internacionales de armonización, siguiendo el modelo farmacéutico de evaluación de medicamentos basada en el sistema de ensayos clínicos multifase.

Palabras clave: Células madre, Medicina regenerativa, Políticas de ciencia, tecnología e innovación, Regulación, Gobernanza tecnológica. 


\section{Introduction}

Throughout the past 20 years stem cell therapies have acquired a priority role in health research agendas worldwide. While the United States, the European Union, Israel and Japan have developed important R\&D programs and specific regulatory frameworks on the subject, many developing countries like India, China, Brazil, Malaysia, Chile and Argentina, among others, have started to implement national strategies for the rapidly developing field of regenerative medicine, through capacity building programs and the effort to create specific regulations (Gottweis; Prainsack, 2006; Salter, 2008; McMahon; Thorsteinsdóttir; 2013; Palma et al., 2015; Sleeboom-Faulkner, 2016; Rosemann et al., 2016; Bin Abdul Aziz et al., 2018, among others).

Stem cells are non-specialized cells that can divide themselves, differentiate into other types of specialized cells, and self-renew in more stem cells identical to the first one. This opens a range of promises for research and clinical practice: scientists expect that by learning to control processes of cell culture, cloning, differentiation and reprogramming, it is possible to produce healthy cells and tissues to repair and/or replace functional or structural tissue or organ damage. Regenerative medicine comprises treatments in which stem cells are induced to differentiate into the specific cells required to repair such damages.

Although the use of bone marrow, peripheral blood and umbilical cord stem cells for treating hematological diseases are common medical practices, the challenge in the past decade has been to use stem cells from these and other tissues to accomplish in vivo or in vitro differentiation in cells from other strains. In particular, the development of the Induced Pluripotent Stem Cells (IPSCs) technique by Shinya Yamanaka in 2006, which involves the ability to generate pluripotent stem cells from adult cells, opened a new set of potential opportunities for drug development, 
disease modeling, and personalized medicine (Gottweis; Minger, 2008; Anastacia et al., 2010; Mikami, 2015)'.

The expectations built by scientists, public officials, the media, entrepreneurs and investors on stem cell development are anchored in their alleged "revolutionary applications": their potential to transform healthcare ensuring cost-effective treatments for diseases with few present therapeutic alternatives, such as cancer, neurodegenerative diseases (Parkinson, Alzheimer), heart failure, diabetes, etc. (Singer, 2008; Mattis; Svendsen, 2011).

So far, these expectations have had a positive economic correlation: different reports have estimated the worth of global stem cell market on 5.17-12.04 billion USD in 2017 and a projected growth to 9.03 billion USD by 2023, with a compound annual growth rate of 9.74\%-13.2\% between 2017 and 2023 (Research Market, 2018; Vision Gain, 2018). While the United States was identified as the market leader, the Asia-Pacific region is expected to record the highest annual growth rate during such period $(11.6 \%)$. These studies show the significant increase in R\&D funding for stem cell research and private investment (both business and venture capital) in the last 10 years.

In this scenario, scholars and policy makers have encouraged capacity building in regenerative medicine as an attractive alternative for developing countries, given the possibility of participating in this market since its early

\footnotetext{
${ }^{1}$ The possibility of reprogramming adult somatic cells into pluripotent stem cells (Induced Pluripotent Stem Cells or IPSCs) from mouse embryonic fibroblasts, reported by Takahashi and Yamanaka in 2006, was highly recognized by the community of stem cell scientists as an important achievement. IPSCs were seen as a promise to overcome some key issues in stem cell research: the ethical concerns related to the use of human embryonic stem cells and the difficulty of obtaining large numbers of adult stem cells. However, there is no consensus on whether ESCs and IPSCs can be treated interchangeably or on the therapeutic usefulness of IPSCs, which is yet to be confirmed. In many cases, IPSCs are used as tools for basic research or modeling diseases in a laboratory, rather than as sources for regenerative medicine (Anastacia et al., 2010; Mikami, 2015). The appearance of IPSCs has also raised questionings on the future of embryonic stem cell research (Gottweis; Minger, 2008).
} 
stages (Greenwood, 1998; Palma et al., 2015). These stakeholders assert that local innovation in this field may lead to more accessible treatments for the population - mainly on non-communicable diseases - and it may provide the technological and cognitive basis for the solution of domestic needs while contributing to health and economic development (Greenwood et al., 2006; McMahon; Thorsteinsdóttir, 2013).

Meanwhile, stem cell technologies have aroused heated debates - both in developed and developing countries - among policy makers, universities, scientists, companies, the pharmaceutical industry, private investors, bioethicists and patient groups (Salter, 2008; McMahon, 2014; Arzuaga, 2014; Luna; Salles, 2014; Palma et al., 2015; Sleebom-Faulkner, 2016). At the same time, these technologies have raised hopes for novel treatments for a wide range of ailments, and expectations for new patentable and marketable developments. They have also stirred up the concern about these treatments' effectiveness, safety and associated risks.

In this scenario, Argentina has been no exception. Since 2006, the Argentine government has considered this technology a "main priority [...] in terms of research and development" (Palma et al., 2015, p. 793). At a national level, it is possible to identify an effective capacity building program and state promotion efforts. Considered a "window of opportunity" for scientific, technological and economic development, Science, Technology and Innovation (STI) agencies have deployed several funding programs, regional networks and dedicated institutional support to create a specific regulatory framework (CONICET, 2012; MSTPI, 2012).

However, at the same time, the construction of expectations on the potential therapeutic applications of this technology has increased. These expectations are usually disseminated by mass media, advertised by cord stem cell biobanks for autologous use ${ }^{2}$ and by clinics, which offer for-profit treatments that are not based on systematic clinical evidence. Hopes and

${ }^{2}$ Autologous use is the use of stem cells by the person from which they were obtained. Allogeneic use refers to the cases when the donor and recipient are different. 
possibilities for these technologies are exchanged in forums that bring together soon-to-be parents and patients with serious or incurable diseases (Krmpotic, 2011). In this scenario, for the past decade, scientists, STI agencies, bioethicists and patient organizations have warned against the risks of experimental treatments and the limitations of cryopreserving cord blood stem cells for autologous use. They have also started shaping a specific framework to regulate these emerging technologies and practices, setting standards in relation to quality, safety and effectiveness.

This paper aims to analyze the process of shaping innovation pathways for stem cell technology in Argentina. We explore how state policies define what constitutes a priority, a desired and acceptable direction for local regenerative medicine, deploying strategies that align diverse actors and materials (funding, capacity building, public advocacy actions, and regulatory initiatives) to establish certain technological development pathways (definitions, processes, legitimized actors and procedures) over others.

We mainly address the agency of the regulation of technological development: how it incorporates visions on what are considered "good", "desirable" and "possible" directions to be undertaken by the state, and how, in turn, it configures the way that actors produce, access and use new technologies. In other terms, we explore how regulation works within the process of technological development as a material matrix of sanctions and rewards, and how it is co-constructed along with public and/ or private investment decisions, capacity building strategies, innovation processes, market structures, infrastructures, production costs, access to goods and services, seeking to establish certain socio-technical dynamics (instead of others). In the stem cell case, we understand this process as a complex negotiation among heterogeneous actors (firms, scientists, regulation authorities, lobby groups, physicians, patients, investment groups, biobanks, health insurances, etc.), who weigh between risk management and expectations, interests and values, benefits and symbolic rewards, safety and efficacy, access and availability. 
This research is based on a qualitative design of documentary analysis based on primary sources (news, institutional communications and press releases, websites, curriculum vitae, R\&D projects, scientific papers, national STI plans, laws, ministerial resolutions, legislative projects, statistics, advertisements, etc.) and secondary sources (scientific papers, technology reports). The topic was surveilled between 2011 and 2018, using material retrieved from 2006 to date. Data gathering was conducted after a "follow the actors" strategy consisting of several nuclei: documents and material issued by the main national STI agencies (the ministry, the research council and the promotion agency), leading scientists, institutions and groups (their projects and trajectories), health regulatory agencies and regulatory key players, patient organizations, and private biobanks and clinics. Changes in the construction of stem cell expectations during the period 2006-2018 were mapped following the media coverage on the matter: in the main national newspapers (La Nación, Página 12, Clarín, InfoBAE, Perfil) and local press (La Voz del Interior), STI national and regional news agencies (Agencia TSS, SciDev.Net, InfoTechnology, Apertura, Materia, NEXCiencia) and law portals (Diario Judicial, Microjuris). In addition, seven in-depth interviews were conducted with scientists, policy makers, regulators from different national agencies and members of patient organizations.

The paper is structured as follows: in the next Section, we will address the main regulatory tensions around stem cells in a global scenario. Firstly, we explore the co-construction between the selection of STI policy priorities and the process of shaping technological regulations. Secondly, building on prior empirical works, we posit four tensions that cross the selection of regulatory pathways for stem cell technologies, as an essential feature in the adoption of national strategies. In the third Section we analyze how innovation trajectories for stem cells and regenerative medicine have taken place in Argentina for the past decade. To that end, we first examine the deployment of state actions on capacity building, orienting them towards expected innovation policy results. Then, in the next two subsections we discuss the creation of new business opportunities in response to patient expectations, particularly cord stem cell banks and the supply of experimental 
treatments. Finally, we return to state led actions that attempt to build a regulatory framework to govern technology development in terms of national envisaged strategies.

\section{Regulatory tensions in a global scenario}

\section{Shaping regulation, shaping innovation}

How do nation-states imagine their technological futures and define the orientation of desired Science, Technology and Innovation (STI) pathways? How does the construction of expectations about technologies (from scientists, patients, companies) intersect with policy decision making on technological development? What is the role of technology regulation on materializing visions on desired futures?

Socio-technical imaginaries can be defined as "collectively imagined forms of social life and social order reflected in the design and fulfillment of nation-specific scientific and/or technological projects" (Jasanoff; Kim, 2009, p. 120). They describe attainable futures, projecting visions on what is good, desirable and worthwhile to be undertaken by the state, linking the construction of expectations and risks with effective exercises of state capacity to influence technological development, in the selection of priorities and allocation of public expenditure. But imaginaries do not exist in a void. They work in a material matrix of sanctions and rewards that shape interrelations of domination and subordination, relative growth, reinforcement, relegation or decline (Therborn, 1989). These visions are built and reproduced through socio-technical coalitions of actors, institutions, technologies and resources (Thomas et al., 2017; Bortz, 2017). They influence the construction of technology and policy preferences, by inscribing these preferences into specific instruments, regulations and forms of intervention ("secondary beliefs") (Sabatier; Weible, 2007).

In turn, public policies constitute a central component of these material matrices in which these visions work: they shape technological 
development, research and innovation trajectories towards those directions that are considered "good", "desirable" and/or "possible (Therborn, 1989). Regulatory shaping, in particular, involves a power exercise, where a multiplicity of actors and elements (technologies, institutions, funding, guidelines, knowledge, ideas and beliefs) intervene, negotiating materials and technological practices, in the attempt to align them with desired paths of technological development and governance. These regulations, in turn, organize spaces, social relations and actors' behaviors; condition structures of social distribution, production costs, access to goods and services; and generate incentives and restrictions through the distribution of benefits and sanctions, seeking to build irreversibility on the status quo (or revert it) (Akrich, 1992, Callon, 1992; Lascoumes; Le Gales, 2007; Thomas et al., 2017).

For the purpose of this paper, we will define "technology regulation" as the attempts made by state agencies "to shape the governance of technology in order to promote the public interest" (van Zwanenberg et al., 2011, p. 12). This definition involves three main points: first, even when regulation is state-centered - given state capacity of legislation and enforcement - the state is not understood as a monolithic actor but rather as multiple actors with diverging interests. They negotiate regulatory frameworks with non-state actors (businesses, scientists, practitioners, citizens, NGO, lobby groups, media, among others). The latter are not considered as mere technology/ regulation users, but as a part of technology governance.

Secondly, regulation is not only understood as an exercise of control on established technology products, processes and practices, but also as the aspiration to direct the development of new technologies. It seeks to ensure that technologies, and the social practices through which they are produced and used, follow one orientation instead of others, stabilizing them in that direction (van Zwanenberg et al., 2011). Third, regulations tend to be presented as serving "the public interest", balancing private interests according to certain collectively agreed principles. Here, "public interest" is considered a contested political ground, whose definition results from 
negotiations between diverse actors to impose their interpretations of what is "good", "desirable" and "possible" (Therborn, 1989).

Public policies are aimed at "providing", "distributing" and "regulating" (Braithwaite et al., 2007). In the case of Science, Technology and Innovation (STI) policy subset, as regulations shape behavior, they also contribute to the ways in which technology development pathways unfold, sending signals (sanctions and rewards) about desirable/undesirable, acceptable/ unacceptable directions of technology development and use. At the same time, STI policies tend to be seen as "distributing" and "providing" activities (i.e. the distribution/provision of human resources training, subsidizing public, private and public-private projects, acquiring infrastructure). However, these capacity-building actions are "also regulating activities, to the extent that they might be designed to encourage public and private actors to create, modify, and diffuse certain kinds of technologies in relation to a broader set of policy objectives and ambitions" (van Zwanenberg et al., 2011, p. 13). Thus, technology regulation not only shapes the ways in which artefacts are used, how and to whom access is provided, but also may influence decisions on state innovation priorities, public and private investment, market structure, among others ${ }^{3}$.

In the case of stem cell therapy development, a key problem has been the inadequacy of existing regulatory frameworks (designed for the clinical testing and market approval of pharmaceutical drugs) in relation to the biological characteristics of stem cells. Regenerative medicine includes a range of techniques and technologies whose goal is to build or restore biological functionality within the body. Its distinguishing characteristics also diverge from molecular or biological drugs in that the aim of this therapy

${ }^{3}$ At the same time, as regulations provide signals about desired (and non-desired) technology development pathways, they cannot manage to impose them on their own. As van Zwanenberg et al. (2011) point out, many other "de facto" governance mechanisms shape technological practice, such as unintended regulatory effects, and the tendency of technology developers and users to reinterpret, evade and seek to shape regulatory norms into better alignment with their own private interests. 
is to not only heal but also to reconfigure the human body at the specific tissue and cell level (Webster et al., 2011, p. 402).

Two main innovation pathways broadly characterize the stem cell research field at an international level: the first involves the development of cell therapy procedures on a patient-by-patient basis (such is the case of autologous use of bone marrow stem cells). The second one, following the pharmaceutical industry business model, seeks to develop a standardized product that can be used as a therapeutic by a large number of patients. The latter tends to use scaled-up allogenic tissue that has been substantially manipulated ex vivo to perform in specific ways (Webster et al., 2011). There, the primary regulatory concern around the development of new therapies is not so much about the origins of the cell (allogeneic or autologous) but about the degree of cell manipulation and whether it leads to a safe standardized product. Trialing stem cell treatments involves a particular set of problems, which diverge from biochemical/industrial drugs. For instance, the scarce knowledge about how regenerative tissues multiply and distribute around the body; how cells proliferate and behave beyond the local setting into which they are introduced; uncertainty about the effects of the administration route; or the oncogenic (cancer-causing) possibilities that different cell-handling procedures may entail (Webster et al., 2011).

In this scenario, state actors, scientists, health administrators and companies have agreed that specific procedures and risks for patients required new and suitable regulatory approaches. Moreover, the negotiation of regulatory frameworks for stem cell therapies has been marked by the widespread surfacing of experimental stem cells interventions on for-profit basis, provided outside multiphase randomized controlled trials (RCT) and exterior to the review of regulatory authorities. The provision of these for-profit therapies has evolved to a lucrative business and to a common practice in many countries (Sleeboom-Faulkner; Patra, 2008; McMahon, 2014; Salter et al., 2015; Rosemann et al., 2016). 
For these reasons, controversies on how appropriate regulation for stem cell-based treatments could look like have dealt with many issues. These converge under the broad umbrella of "risk" and "access" and range from discussions of ethical limits, to clinical methods, effectiveness, quality, safety concerns, the development of scientific standards that are considered "good", "desirable" and "feasible" for human health application, to matters of intellectual property and the availability of new treatment options to patients (Rosemann et al., 2018).

\section{Four tensions for stem cell regulatory development}

Building on previous empirical works, an international comparison of seven jurisdictions (United States of America, European Union, Japan, China, India, Argentina and Brazil) has indicated the emergence of a high level of variation in stem cell regulation (Rosemann et al., 2016). Regulatory developments in these jurisdictions unfolded between two central dynamics: attempts for harmonization vs. a process of regulatory diversification (Rosemann et al., 2016).

Moves towards normative harmonization are oriented to international collaboration in R\&D, trans-national clinical research and cross-border economic activities for the global market (Sleeboom-Faulkner et al., 2016). This trend, led by regulatory authorities in the United States and the European Union (EU), is exemplified by legislative instruments such as the Regulation for Human, Cellular and Tissue Products (HCT/Ps) in the USA, and the Advanced Therapy and Medicinal Products (ATMP) legislation in the EU (both in 2007), and the Guidelines for Stem Cell Research and Clinical Translation by the International Society for Stem Cell Research (2008). These harmonization processes have evolved from a pharmaceutical model of drug development and the ideal of evidence-based medicine (EBM), with the multiphase randomized controlled trial (RCT) system as the methodological gold standard. This tendency aimed to facilitate particular forms of global stem cell governance, framing the room for maneuver for national regulators, including capacity-building processes that may be required to adapt local capacities and processes to global standards. 
On the other hand, there is an increase in the emergence of alterstandardization politics that propose alternative methods and forms of evidence for clinical innovation in the stem cell field, to reduce the costs of clinical testing and to increase access to non-systematically proven innovative interventions at an earlier stage. Many of the regulatory impulses that shift away from RCTs have come from Asia, in countries such as Japan, India, China, and South Korea (Sleebom-Faulkner et al., 2016), but some of them have also started to be considered by the US or EU health authorities. As pointed out in earlier works, these clashes have resulted in four central dynamics of regulatory diversification (Rosemann et al., 2018):

(a) A "cells-as-drugs" approach for stem cell treatments, which is based on the EBM/multi-phase trial system and follows from the Big Pharma model of drug evaluation (as described above).

(b) The emergence of a growing number of regulatory exceptions and exemptions, such as "hospital exemptions", "compassionate use programs" or "fast track approvals", adopted in the European Union and United States;

(c) The flexible enforcement of regulatory standards, implicitly enabling the persisting supply of experimental for-profit interventions, outside the control of regulatory agencies. This trend has been prevalent in China and India but also observed in the United States; and

(d) The abandonment of multi-phase randomized clinical trial systems, allowing the conditional, limited term market approval of stem cell products after early-phase clinical trials with a small number of patients, as has happened in Japan. The Japanese model is likely to influence regulatory schemes in other countries, or at least to result in the creation of additional types of regulatory exceptions for conditional market approval of stem cell therapies sidelining Phase I-III of clinical trials.

The development and selection of regulatory alternatives for stem cells implies complex negotiation processes among stakeholders (firms, scientists, 
regulation authorities, lobby groups, physicians, patients, investment groups, biobanks, health insurances, etc.). These different regulatory models weigh between diverse options that entail benefits, risks, interests and values in terms of economic competitiveness and business profit, safety and efficacy control, widening/restricting people's access to healthcare goods and services (Vasen, 2008).

In this context, four main tensions have been identified (Rosemann et al., 2018):

(a) International integration and access to global markets vs. the facilitation of local innovation and business opportunities. Pressures for international regulatory harmonization arise from demands for participation in international research and global markets, mainly in developed countries. International harmonization of medicine regulation typically evolves around the use of multi-phase clinical trials, with the aim to achieve international safety standards, enabling the creation of new economic opportunities and possibilities for joint innovation, increased availability of health-related products and services, and the uncomplicated circulation of (biological) materials, patients and professionals. But, at the same time, it implies an increase of development costs for new drugs and biological products and it also tends to raise the entry barriers, especially for scientists and companies in developing countries and for small and medium companies more generally. These can often not afford to comply with international regulatory requirements.

For these reasons, national governments and regulatory bodies are confronted with a tension between aspirations to achieve access to global markets and international integration, and the facilitation of national homekeeping strategies that allow for the development and protection of domestic market and innovation opportunities. This tension is particularly pronounced in low-to-middle income countries, where innovation strategies evolve in relation to locally available resources, local innovation ambitions and domestic health care priorities (Sleeboom-Faulkner et al., 2016). 
(b) Rapid development of - and early access to - new medicines vs. the systematic testing of safety and efficacy. The second tension emerges from the demands from citizens and patients to obtain access to novel medical solutions and investigational products more rapidly and under a personal autonomy stance. This claim conflicts with the slow process of evidence-based drug development, which requires solid scientific evidence of efficacy and safety for their approval. In recent years, a growing movement has advocated for right-to-try medicine, which has resulted in regulatory adjustments and revisions (Salter et al., 2015). But acceleration of the drug development process has also been promoted by the pharmaceutical industry, which has lobbied for the adoption of fast track review and marketing approval mechanisms (Rosemann et al., 2018).

(c) The realization of affordable medicines vs. the generation of corporate profits. The rising costs of drug development under evidence-based medicine standards and the pursuit of biotech and pharmaceutical companies to generate profits from newly developed drugs, comes into tension with the capacity of health insurance systems and individuals to afford and provide access to new treatments. This tension is especially significant in developing countries, but with growing inequalities, shrinking healthcare budgets and aging populations this is a problem also in high-income countries. At the same time, demands for more affordable drugs and the creation of regulatory alternatives (that lower the costs for drug development) conflict with the need to assure safe and efficient therapeutics. This tension challenges the assumption sustained by scholars and policy makers that stem cell innovation in developing countries will lead to more accessible treatments (Greenwood et al., 2006).

(d) State led forms of regulatory control vs. deregulation demands. Regulatory frameworks for new medicines' approval have been state-led, and co-produced with the pharmaceutical industry, establishing procedures that seek to protect the interests of drug producers and the safety of patients and trial participants. However, recent years have shown increased calls among both patients and corporations for deregulation, to facilitate broader 
individual choice, more affordable drugs and the provision of (often nonsystematically proven or experimental) therapies that would not normally be permitted by drug regulatory authorities. This has aligned a new coalition of some patient organizations, researchers, free market health advocates, private clinics and small-to-mid-size biotech companies that seek to maximize experimental and clinical freedoms, and to minimize the regulatory controls and the costs for drug approval (Rosemann; Chaisinthop, 2016). In those cases, patients have become liable for the costs and consequences of these experimental treatments.

As was stated afore, the ways in which governments and regulatory authorities respond to these tensions and conflicting regulatory choices are not only a matter of "control", but they create different types of (statedesired) futures for technological development, which affect issues such as, priority selection, allocation of public expenditure, capacity building, the construction of expectations, accessibility and risk management.

The following section will explore how stem cell technology development has been configured in Argentina. This process will be addressed by reflecting on the tensions between (a) state capacity building strategies (under the assumption that they constitute an "opportunity" for technological development); (b) the emergence of new businesses and business opportunities (in part related to patients' expectations); (c) and the configuration of a regulatory framework (still in the making) that responds to growing concerns about the risks of this new life technology.

\section{Shaping stem cells innovation pathways in Argentina}

\section{Governing $R \& D$ capacities}

In Argentina, Science, Technology and Innovation authorities have considered stem cell technology as one of the main "strategic socio-productive nuclei" within the health sector at the national STI plan (MSTPI, 2012). Since 2006-2007, it is possible to see the construction of this technology 
as a "state priority in terms of research and development" (Palma et al., 2015), based on a growing trend of institutional creation, funding programs, regional network generation, and attempts towards technology regulation.

STI agencies, officers and key researchers signified technology investment in this early stage as a "window of opportunity" to bring the country closer to the "technological frontier".

The Ministry's strategy on regenerative medicine and cell therapies is "to act as a bridge between basic research and clinical research, generating a strategic plan for development and investment in this subject". [...] The work in this area is of particular importance for Argentina [...] "the issue is new, so we see that it is a great opportunity for the development of this branch of science in our country" (MSTPI, 2008, emphasis added).

The possibility of making a biotechnological platform to produce cells from reprogrammed cells is a golden opportunity (interview by CONICET with a stem cells leading scientist) (CONICET, 2012, emphasis added)

This meaning attribution is also reinforced in the description of funding instruments:

[...] oriented to provide reference infrastructure in state-of-the-art technologies and to generate capacities in fields of knowledge [...] in which current practical applicability is uncertain but that are vital to take advantage of new or possible 'windows of opportunity' or to position themselves in the technological frontier (MSTPI, 2011, p. 20, emphasis added).

These actors considered its character as an emerging technology a privileged opportunity for playing science and technology catch-up: that is, to carry out learning processes and accumulation of knowledge and skills in advantageous conditions, at a time when entry barriers into R\&D, production and design of new technologies are lower. It aims to achieve autonomous capacities and establishing R\&D policies that may reduce the technological distance between developed and developing nations (Pérez, 2001; Greenwood et al., 2006; Bortz et al., 2018). 
Under that vision, the first specific policy action towards stem cell promotion was the creation of the Advisory Committee on Cell Therapies and Regenerative Medicine (ACCTRM) in 2006, organized by the president of the National Agency for the Promotion of Science and Technology, then transferred to the Ministry of Science, Technology and Productive Innovation (MSTPI) in $2007^{4}$. The committee is composed by 16 members, including biologists, medical doctors, bioethicists, lawyers, and regulators. It aims to advise the government and general public on bioethical, legal, and scientific issues related to regulation, promotion and dissemination of research and clinical therapies involving stem cells. Also, it plays a leading role in Argentina towards advocating against non-authorized stem cell treatments and advising on the development of a legal framework.

Given that orientation, one of the main courses of state action in recent years has been aligning public investment for capacity building through a set of specific promotion and funding instruments. Among them: financing a stem cell research consortium (CICEMA, in 2008), composed of 10 institutions including basic, translational and clinical research groups, a technological linkage unit, foundations and private companies ${ }^{5}$; and financing the Human Reprogrammed Stem Cell Platform (PLACEMA, in 2011), aimed at building capacities in reprogrammed stem cells and cellular differentiation, oriented in turn towards its potential clinical application and transfer to industry ${ }^{6}$.

\footnotetext{
${ }^{4}$ In September 2018 the MSTPI was downgraded to a Secretariat within the Ministry of Education, Culture, Science and Technology. Documentation on the ACCTRM has not changed since that process to the moment of witting this document.

${ }^{5}$ The project was financed through the Strategic Action Program (PAE 37075): "Crosssectional and multidisciplinary study on the therapeutic use of genetically modified stem cells" (2006-2010). This first specific funding for stem cells involved funding of 2.5 million U.S. dollars allocated by the National Agency of Scientific and Technological Promotion (ANPCyT) to a consortium of ten public and private institutions (research institutions, medical centers and biotech companies).

${ }^{6}$ The Human Reprogrammed Stem Cell Platform (PLACEMA) seeks to develop and provide reprogramming and cellular differentiation services to R\&D groups and the pharmaceutical industry.
} 
In terms of international cooperation, in 2008 a binational agreement with Brazil was established (PROBITEC, in 2008) to train human resources and assign specific funding for basic, translational and clinical research $(2011)^{7}$. This initiative emerged from an international symposium coorganized between the MSTIP with the International Society for Stem Cell Research (ISSCR), gathering scientists from United States, Europe and Latin American (Pitossi; Podhajcer, 2014).

As regards human resources training, since 2012 regenerative medicine also became a priority window for fellowship calls and accessing research tenure track at the national science and technology council.

These efforts have resulted in a process of building endogenous R\&D capabilities. In institutional terms, these have converged especially in around ten R\&D units, which are national referents in the field since the early $2000^{8}$, mainly concentrated around the Buenos Aires Metropolitan Area. These centers and research institutes are presented - for the moment - as the main stem cells research, development and innovation loci, and also of human resources' training. Since 2011, capacity building on stem cells has also spread into new institutions ${ }^{9}$ in the Buenos Aires Metropolitan Area, to other regions in the Buenos Aires province, to other big Argentine provinces, such as Córdoba, Santa Fe, and, more incipiently, in Mendoza, Neuquén and Tucumán.

\footnotetext{
${ }^{7}$ Under this initiative, the ANPCyT issued in 2011 two competitive funding calls for research projects: the first one, aimed at basic and translational research, and the second one oriented to clinical stem cells' applications, giving priority to research on cardiovascular, autoimmune, bone, cartilage, diabetes and cancer diseases.

${ }^{8}$ Fundación Instituto Leloir, Fundación FLENI, Hospital Italiano, Universidad de Buenos Aires (School of Exact and Natural Sciences, School of Medicine and School of Pharmacy and Biochemistry), Hospital Garrahan, Fundación Favaloro, Universidad Austral, Instituto de Biología y Medicina Experimental (IBYME-CONICET), Fundación Pablo Cassará.

${ }^{9}$ In Buenos Aires City and Province, institutes such as Universidad Nacional de San Martín, Instituto de Investigación en Biomedicina de Buenos Aires-CONICET-Max Planck, Universidad Nacional de Mar del Plata and Instituto de Investigaciones Bioquímicas de Bahía Blanca. In Córdoba, Universidad Nacional de Córdoba, and in Santa Fe province the Universidad Nacional de Rosario and Instituto de Biología Molecular y Celular de Rosario.
} 
In terms of funding, public support resulted in growth: from 18 projects funded in 2008, to 47 in 2012 (Pitossi; Podhajcer, 2014; Palma et al., 2015) and over 100 in 2018 (SICYTAR, 2018). Currently, 88\% of assigned projects have been concentrated between Buenos Aires city and Buenos Aires province, $5 \%$ in Córdoba, $3.4 \%$ in Santa Fe. The process of capacity building within these years has resulted in an estimate of over 400 researchers (tenured researchers, postdoc, $\mathrm{PhD}$ and fellows) who have received training in this technology (SICYTAR, 2018).

Among the main research lines are cell differentiation and reprogramming, improvement of culture media for stem cell proliferation and preservation, with a convergent focus on neuroscience (especially neurodegenerative diseases), oncology, cardiology (including Chagas disease), metabolic diseases (such as diabetes), dermatology, ophthalmology, among others. Studies have been conducted mainly on hematopoietic, mesenquimal and neural cells, and over 50 researchers were registered to be working on induced pluripotent stem cells (SICYTAR, 2018). At least four groups have worked articulating stem cells with gene editing techniques.

In general terms, most of them fall firstly, within the scope of basic research and, secondly, in pre-clinical research. Four clinical trials were registered: the first one, carried out in 2005, for the treatment of chagasic cardiomyopathy with autologous cells. Since 2012, three other Phase I trial protocols were approved: studies on the effects of adult stem cells (hematopoietic precursors) on stroke patients; efficacy of autologous donation for the treatment of cartilage lesions; use of mesenchymal stem cells for skin regeneration in patients with severe burn injuries. These are carried out through partnerships between R\&D institutes, private companies and hospitals.

Researchers from the above-mentioned main $R \& D$ units have been important advocators of state support to this field, in a process of coproduction of institutional, regulatory and funding initiatives. 
However, the growing scientific interest in stem cells and the exponential process of capacity building in the last decade, has not correlated with the research activities of technology-based companies. STI policy makers argue that this disinterest from local industry is due to the need for additional hospital infrastructure and the uncertainty regarding return of investment. To date, most of stem cell-related R\&D work has been carried out in research institutes and centers, mostly with state funding. In the few cases of company participation, the focus has mainly been on partnerships with public institutions.

Diverse actors assess that factors that may affect negatively on private sector participation are, firstly, the problem of defining the character of cells and stem cells as a product or as a procedure. This influences the possibility of scaled production and, consequently, the likelihood of obtaining returns from the high R\&D investment. Secondly, the high costs involved in conducting multiphase clinical trials. Third, the lack of an established regulatory framework for stem cells (i.e. the lack of "good practices" for research and therapy provision) and of the intellectual property mechanisms. This generates an uncertain picture concerning the possibilities and ways of economic and/or social appropriation of these developments. This situation may also be related to a general tendency in Argentina of low private sector participation in innovation activities (16.4\%), which is even lower than the Latin American average ${ }^{10}$ (RICYT, 2017).

\section{Cord cell banks: promises in the face of anticipated disease}

With the notable increase of scientific, medical and commercial interests in the alleged properties of umbilical cord blood stem cells ${ }^{11}$ (one of the areas that has most rapidly multiplied in the private sector), biobanks have

\footnotetext{
${ }^{10}$ Government participation in R\&D expenditure in Argentina was $77 \%$ versus $16.4 \%$ by public and private companies. The average for Latin America is $59.1 \%$ and $36.7 \%$, respectively (RICYT, 2017).

${ }^{11}$ Since the late 1980s, umbilical cord blood has been perceived as a valuable source of hematopoietic progenitor cells, considered an alternative source for bone marrow and peripheral blood in the treatment of various hematological diseases. Degenerative diseases of the nervous system are presented as an attractive target for therapy with cord stem cells.
} 
started to offer new options for the collection, processing and storage of cord blood and placenta stem cells. These cells can be used for potential autologous use and direct family use (Guardar células madre..., 2011).

Seven main institutions provide this service, currently grouped in a single association. Storing umbilical cords in a private bank costs between 1000 to 1500 USD and a 100-180 USD yearly fee as a maintenance service (Garau, 2015; Células madre: buscan regularlas..., 2018). In 2015 it was estimated that 10,000 people per year decide to keep umbilical cord tissues to prevent future emergencies with a trend of $15 \%$ annual increase (Garau, 2015).

The over-optimistic coverage about the potential of umbilical cord blood stem cells storage for autologous use and stem cell therapies has been promoted by private stem cell banks and widely disseminated by the press (Guardar células madre..., 2011; Hartman, 2017). The advertisements of these institutions have become available at gynecological clinics, medical centers' websites, as well as maternity and health publications, appealing to the individual responsibility of new parents on the future health of their children. They also refer to the unique timing of childbirth for ensuring access to these cells, which can then (reportedly) protect the newly born child in the future. Discourses sustained by these actors emphasize its use for the treatment of diseases such as leukemia, metabolic diseases, cartilage and bone regeneration and heart failure. These companies affirm the utility of cellular material storage on the assumption of its potential use for therapeutic applications.

Parents are assigned the "responsibility" to make a decision that would (potentially) protect their children's health ${ }^{12}$. This decision is of a preventive nature: these initiatives advertise an "opportunity" to be prepared for the "medicine of the future" (Krmpotic, 2011) and for potential (still unknown)

12 Biobanks refer to this "responsibility" with advertising copies such as "Always at the forefront to help you protect what you most love", "Take the most important decision for your child's future today: keep the cells", "Developing tools for regenerative medicine and for the future of who you most love" (Bortz et al., 2017). 
risks. Since umbilical cord blood or placenta storage does not guarantee subsequent access to treatments, keeping stem cells from cord blood appears as an uncertain technological alternative for an uncertain problem.

The coalition sustained by the MSTPI, scientists, bioethicists, patient organizations, the Cord Blood Public Bank, and regulatory authorities warn against these services. In the controversy over the modes and criteria for storage and use of cellular material (public or private), the ACCTRM, warns against the risks of private banks, which "perform misleading propaganda by exalting the curative potentials in several diseases when there is still no clinical evidence for it", given that any use of umbilical cord blood stem cells, other than bone marrow transplantation, is experimental (ACCTRMMSTPI, 2009b).

The Cord Blood Public Bank of the Garrahan Children's Hospital'13 shares this position. The bank reinforces a conception of cellular material as a public good and a "solidarity" system for donation and use ${ }^{14}$ (Stekolschik, 2008; Hartman, 2017). However, despite the official position on this issue, the regulation on the subject, which is still recent, has not managed to place too many restrictions on the supply of such services and attempts made for regulation have not thrived as law (Krmpotic, 2011).

\section{The supply of experimental treatments}

The supply of clinical stem cell interventions without systematic testing and oriented towards commercial purposes has multiplied worldwide, to the extent that some authors have characterized it as the emergence of a

\footnotetext{
${ }^{13}$ The Public Cord Blood Bank of Pediatric Garrahan Hospital, created in 2005, is part of the international network Bone Marrow Donors Worldwide.

${ }^{14}$ Among the arguments that support this stance are: (a) the uncertainty about the duration of cryopreserved cord cells; (b) the possibility of using own hematopoietic stem cells in case of need; (c) the recommendation not to use the patient's own stem cells to treat a cancer or immune disorder, being only advisable to store the blood of a child when there is another child in the family who has or has had one of the diseases that can be treated with bone marrow transplantation, and even so, scientist sustain that there is only a $25 \%$ chance of compatibility.
} 
"global industry" of experimental stem cell interventions (McMahon, 2014). It is estimated that since the year 2000, several hundred thousand patients have received stem cells experimental treatments, offered at prices ranging from 5,000 to 50,000 USD, and up to 100,000 .

In Argentina, the ACCTRM-MSTIP appraises that around ten institutions are offering treatments in Argentina that have not undergone clinical trials, framed as professional "medical practices". They supply from esthetic interventions to stem cell autotransplant treatments for brain or spinal cord injuries, neurodegenerative and metabolic diseases (ACCTRM-MSTIP, 2009c; Grippo, 2013). There are also representatives from clinics based in other countries -mainly China and United States (Ferreras, 2012) - offering medical tourism services to patients with orphan or incurable diseases, or with minimal healing expectation.

These practices gained resonance with stem cell media coverage, having great influence on public opinion and patient individual decisions. This includes news about the "healing capacities" of stem cell therapies to charitable campaigns to raise funds to help ill children to afford their costs (Ferreras, 2012; Grippo, 2013; Furor solidario..., 2014).

The growing supply of these treatments has also affected local health systems. The refusal of private health insurances and public healthcare services to finance these treatments resulted in lawsuits and requests for legal protection from various patients. Between the lack of specificity of the current regulatory system and the demands of desperate patients, some judges have decided in favor of patients and forced public and private health services to cover experimental treatments (Arzuaga, 2013; Las prepagas..., 2011). In other cases, the refusal of health care systems has led to the above-mentioned charitable fundraising campaigns.

Patients play a notable role in this "tissue economy". They become acquainted with experimental treatments through recommendations from friends or relatives, website searches, discussion forums, referral from other 
medical practitioners, driven by the pressing character of their ailments. The demand for experimental treatments in Argentina does not appear as "organized hope" but rather as individual quests based on the belief in cure, which often weighs stronger than scientific, political or legal evaluation (Krmpotic, 2011). It remains a personal and private negotiation between the pressure of the ailment and the risk of the treatment. The results of these interventions range from testimonies that indicate improvement to claims and lawsuits for deception and fraud due to ineffectiveness, unwanted effects or even death (Krmpotic, 2011; Grippo, 2013).

Against this backdrop, the coalition aligned by the MSTPI (which includes scientists, health regulatory authorities, bioethicists and the Public Blood Cord Bank), gathered in the advisory committee on cell therapies, discussed the problem of hyped expectations and healing promises among patients by the media, private cord banks, and clinics.

The ACCTRM published numerous press releases, specifying the approved treatments (transplantation of bone marrow stem cells, peripheral blood and umbilical cord and autotransplantation of bone marrow and peripheral blood stem cells to treat blood diseases) and warning against the uptake of other treatments without appropriate evidence of safety and efficacy (ACCTRM-MSTPI, 2009a; 2009c; 2012). Unlike the biobanks, which frame "risk" as the future in which we can all be potentially sick, actors gathered at the ACCTRM focused on present biosafety risk of therapies that do not meet the criteria of evidence-based medicine. They also refer to the economic imbalance of these treatments for the public health system (Arzuaga, 2013).

This stance also aligns with the strategy of local patient organizations. Far from advocating for deregulation or the creation of regulatory alternatives to access experimental treatments, many organizations have raised awareness on the diseases and the risks of experimental therapies; denouncing the construction of "unreasonable expectations" from media coverage 
("Levántense y anden", 2015) and advising patients who seek for these alternatives (De Santo, 2014).

The Argentine Federation of Rare Diseases, which groups over 30 member associations and patients groups ${ }^{15}$, leads these initiatives. Under the auspices of the MSTIP, the Federation and the ACCTRM launched the Argentine Network of Patients for Advanced Therapies (APTA Network) in 2013. This network provides a space for dialogue among scientists, regulators and organized patients. The creation of this network also involved the advice and support of the Genetics Policy Institute, which helped defining objectives to help Argentine patient groups to organize as a national network and to "create critical mass" (FADEPOF, 2013). The network's aims were to coordinate efforts, raise awareness about cellular therapies, promote legislation, position this issue on the public agenda and inform patients and their families about advances in stem cell research and the risks of experimental treatments (FADEPOF, 2014). The APTA Network has established links with research groups, funding agencies, regulatory bodies, international patient advocacy groups and other relevant actors, and it aims at strengthening the voice of patients in the field of advanced therapies (FADEPOF, 2013).

Allied with scientists from Argentina and abroad, and mobilizing scientists, authorities and resources, patient organizations have begun generating local records of pathologies, setting up medical histories, building international databases and further ties with international patient groups. They advocate the development of new studies validated through clinical trials: trials that are approved by the competent regulatory authorities, with informed consent procedures, free to patients, and with detailed followup of patients and possible future complications (FADEPOF, 2013; 2014).

${ }^{15}$ The network gathers patient organizations on Scleroderma and Raynaud, Neurofibromatosis, Wilson's disease, Primary Immunodeficiency, Parkinson's disease, Psoriasis, Myeloid Leukemia, Alzheimer's, Huntington disease, Ataxias, Amyotrophic Lateral Sclerosis, Thalassemia, Crohn's Disease, among others. 


\section{Regulation: the strive to govern innovation pathways}

In Argentina, the process of building a specific regulatory framework for stem cell and advanced cellular therapies is still in the making.

Legislation on the subject include the Medicines Act (1964), the Professional Practice of Medicine Act (1967) and the Transplant Act (1993). More recently, in 2007, the Argentine Ministry of Health issued the Ministerial Resolution 610/2007 for clinical use of stem cells in Argentina. This resolution states that the use of human cells comes under the authority of the Unique Central Institute for Ablation and Implantation (INCUCAI) ${ }^{16}$. By coming under the authority of INCUCAI, stem cell interventions are not regarded as a medical product (as in the EU, USA and India), but as a medical procedure, managed by the Argentine Transplant Act.

Decree 512/95 specified that, with the exception of hematopoietic cell transplants from human bone marrow, all types of stem cells should be considered experimental and subject to evaluation of safety and efficacy through clinical research (Arzuaga, 2013; Harmon; Kale, 2015). New experimental practices require authorization of INCUCAI for research protocols ${ }^{17}$. A subsequent resolution issued by INCUCAI stipulated a technical standard to establish requirements and procedures for the preparation of

\footnotetext{
${ }^{16}$ Since 2001, the INCUCAI has been appointed as the organism in charge of the National Donor Registry of Hematopoietic Progenitor Cells (HPC) (Act 25.392/2001 and INCUCAI Res. 319/2004). In subsequent resolutions, the institute was the one to establish the classification of medical indications for autologous or allogeneic transplantation of HPC (Res. 307/2007), the procedures for tissue banking, including the banking of stem cells from umbilical cord blood (UCB) and regulating the activity of UCB banks (Res. 069/2009).

${ }^{17}$ Subsequent dispositions by the health authorities have regulated on good clinical research practices, including requirements of informed consent of research subjects, approval by ethics committees, and gratuity in the participation in the procedures (e.g. ANMAT Dispositions 5330/1997 and 6677/2010). The new Nation's Civil and Commercial Code (Law 26.994/2014) incorporated in 2014 "Personal Rights and Acts" (Chapter 3), regulating through Art. 58 research in human beings. It prescribes the need of clarity in project formulation, professional qualifications, approval by ethics committees, authorization by public agencies, risk assessment, informed consent, protection of intimacy, gratuity of participation in clinical research, among others.
} 
cellular products (Resolution 19/2012), aligned with international standards of good laboratory and manufacturing practices (Arzuaga, 2013).

In the late 2000s, a dispute emerged among Argentina's regulators whether stem cells should be regulated as a medical product instead. This entails not only a matter of political governance but also the need of new therapies to undergo Phase I-III clinical trials for their approval. As a result, Argentina's National Administration of Drugs, Food and Medical Technology (ANMAT) started to play a major role in regulating the use of stem cells.

A first step in this direction was achieved in 2011 by ANMAT regulation 7075 that sets the general requirements for market approval of biological drugs. More than minimally modified cellular products were classified as advanced therapeutic medicinal products (ATMP), together with gene therapy and tissue-engineered products. This follows the "cells-as-drugs" approach of the United States and the European Union which is enforced through the Regulation for Human, Cellular and Tissue Products (HCT/Ps) in the USA, and the Advanced Therapy Medicinal Products (ATMP) in the EU, both issued in 2007. These regulatory approaches frame stem cells as a product and establish a risk-based distinction between (i) minimally manipulated stem cells for autologous use, and (ii) more than minimally manipulated stem cells for allogeneic use. While the former come under the human tissue regulation and do not require prior approval by health authorities, the latter become subject to prior approval by the respective drug regulatory agencies (Rosemann et al., 2016).

During 2017 and 2018, an interministerial workgroup that included professionals from both the Ministry of Health and the Ministry of Science, Technology and Innovation was created (Joint Res.-E1/2017). It aimed to clarify the competencies of ANMAT and INCUCAI and draft better regulations in the area (Células madre: buscan regularlas..., 2018).

As a result, a specific regulation on ATMPs (ANMAT 179/18) was issued in September 2018. This rule includes more specific definitions of the 
products that fall within the ATMPs subcategories of cellular therapy, gene therapy and tissue-engineered products. In addition, it provides a clearer guidance on the role and legal competencies of INCUCAI and ANMAT. The former will be responsible for regulating the donation, obtention and verification of cellular tissue. In turn, ANMAT will oversee the production, registration, approval and surveillance of ATMPs. The manufacturing site will have to follow manuals of Good Manufacturing Practices and clinical trials will have to comply with the same Good Clinical Practice guides that apply to all clinical research. It is expected that INCUCAI will issue shortly specific regulations for the stages of ATMP development that fall within its competence. The two agencies are expected to work in a more coordinated fashion in the future.

However, the current legal reach of both INCUCAI and ANMAT is limited. Argentina is a federal country in which national regulatory authorities have legal power only when medical products cross provincial borders or are involved in foreign trade. As a result, national regulations are not applicable at the provincial level when medical procedures are applied exclusively within the provincial jurisdiction (Arzuaga, 2013). This also leaves room for situations where treatments are manufactured and provided to patients completely within a single health facility, so-called "hospital exemptions".

The current state of the regulatory framework opens a grey area for the provision of experimental treatments outside evidence-based medicine, within a de facto "governance vacuum" (Sleeboom-Faulkner; Patra, 2008; McMahon, 2014). While unproven treatments are framed as professional medical procedures, and those procedures remain within their own local jurisdiction, authorities are inhibited to act ex-officio. This is the main concern of regulators and the new rules that are being drafted aim to narrow down this grey area. With that end, the ACCTRM announced that a new specific bill is being drafted by the Health-STI interministerial workgroup, and expected to be filed in 2019 (Células madre: buscan regularlas..., 2018). 
Two likely persisting restraints on the new regulation will be, firstly, the problem on establishing a punitive system on medical professionals, bypassing local collegiate associations. Secondly, the persistence of a legal vacuum on the registration and control of private umbilical cord blood banks (Hartman, 2017).

For the STI authorities, configuring a regulatory framework to govern stem cell clinical research and treatments has been considered a priority action for over a decade (MSTPI, 2012), along with an intense capacity building program. In the regulatory choice process, heterogeneous local stakeholders gathered around the stance that flexible standards affect the credibility of locally developed stem cell therapies within the global market, rejecting the assumption that rapid market approval may generate higher domestic economic benefits. Therefore, national investment was directed towards R\&D activities that might be of greater value in the long term, oriented towards the global market.

The current state of regulatory shaping shows a large coalition, supported by the ACCTRM, which aligns the MSTPI, scientists, bioethicists, patient organizations, doctors, the Cord Blood Public Bank, the Ministry of Health, ANMAT, INCUCAI and, on an international level, the ISSCR and foreign regulatory agencies. This coalition converged on defining the object of regulation as a product (a biological drug) - foreseeing differences related to levels of cell manipulation -, and the regulatory purpose to "ensure the safety, quality and efficacy of the products and treatments that are prescribed to patients" (MSTPI, 2016). To that end, capacity building, in scientific and regulatory terms, is seen as a requirement to reach global standards.

The national orientation on stem cells has leaned towards regulatory harmonization with international standards, compatible with the United States and Europe. These provisions involve extensive preclinical evidence, the use of Phase I-III clinical trials and international good practice standards. This direction enables the participation of potential Argentine stem cell products in the global market while it raises the entry barriers for 
researchers and Argentine biotech companies. It may also provide more reliable knowledge about the safety, quality and efficacy of new treatments, safeguarding patients. However, there are questions that still remain to be answered. For instance, what are the local funding capacities to sustain long-drawn-out multi-stage clinical trials? Do the productive capacities to manufacture and commercialize these national developments exist? What are the social expenditure capacities to include these therapies within collective health systems?

\section{Conclusions}

For the past decade, Argentine STI policy makers and scientists have considered stem cell technologies a window of opportunity for national positioning at the technological frontier, participating in a global R\&D dynamic since its early stage. To that end, they deployed institutional, regulatory and financing actions to build endogenous capacities in the area, according to international standards.

We have analyzed technology regulation as an essential feature in the adoption of national strategies, aiming to embed visions into desired technology paths and to shape how these emergent technologies are/will be produced, accessed and used. The configuration of a specific normative framework creates (an at least temporary stage of) closure and favor one technology option over others. It does so by defining the object and by establishing standards for safety, efficacy and risk, as well as acceptable processes and legitimized actors and procedures. Stem cell regulation in Argentina has been a long-standing process that is still in the making. As part of this process, a heterogeneous coalition emerged that aligned the STI sector with bioethicists, regulators, health authorities, patient organizations, and public cord biobanks, among others. These efforts were met with opposition by another (more diffused) stakeholder coalition, which comprised private stem cell clinics that supply treatments, private cord blood banks, individual patients, soon-to-be parents' forums and mass media, spreading un-evidenced expectations on this technology. 
Building on previous works, this paper also aimed to position the Argentine case within global regulatory trends for stem cell medicine. Since the early 2000s, Argentine STI authorities adopted an official stance that aligned with harmonization trends led by the regulatory agencies of the United States, the European Union and the ISSCR. Although some regulatory initiatives that aimed to broaden access to investigative medicines were adopted by regulators in Argentina (such as a compassionate use program), the country's position remains under the paradigm of evidence-based medicine and the use of multi-stage, randomized clinical trials (RCT) as methodological gold standard. This diverges from other developing countries such as China and India, which allowed for a more flexible enforcement of regulatory standards that enabled the toleration of non-systematically proven, experimental for-profit therapies with stem cells for many years. Moreover, the abandonment of RCTs and the introduction of early stage conditional market approval which could be observed in Japan, seems unlikely to happen in Argentina.

The persistence of legislative loopholes and ambiguities, the characteristics of the federal Argentine system, and the soft enforcement capacities of the agencies generated a legal 'grey area' for the supply of experimental unproven treatments. ANMAT regulation 179/18 on ATMPs and the forthcoming INCUCAI rule are expected to tackle this situation and limit the availability of experimental treatments outside the multi-phase clinical trial pathway.

In the second section, we sketched four tensions linking regulation with national innovation strategies:

(a) International integration to global markets vs. domestic innovation business opportunities. This opposition appears as false to Argentine authorities, under the policy belief that an alternative regulatory framework will not foster domestic stem cell innovation and competitiveness. Given a small internal market for these therapies, national strategies were oriented 
from the start with a global export scope, requiring harmonized standards for research and product development.

(b) Rapid and early development vs. systematic testing. The coalition supporting stem cell technology policy in Argentina has clearly aligned with the second stance. However, even when local basic research is taking place at the technological frontier, the capabilities and resources to enable clinical translation through RCTs are still at an early stage. In order to change this situation, new administrative capacities are required to guide clinical testing. But above all, financial and infrastructure capacities are required that enable national laboratories and firms to conduct Phase I-III systematic testing, so that compliance with international standards (as required by Argentina's regulatory authorities) can be achieved.

To date, most stem cell research has been conducted with public funding. The availability of private financing for innovation in Argentina is limited (from either companies or investment funds). The effective possibility of locally developed products accessing the domestic and global market requires more than $R \& D$ grants. It necessitates the availability of sound funding to meet the costs of expensive RCTs, in a context where the effectiveness of candidate therapeutic applications is still uncertain.

(c) Affordable medicines vs. corporate profits. At present, the discussion on the accessibility and affordability of new medicines relates especially to the topic of free access to clinical trials, as opposed to the provision of for-profit treatments in clinics, which has been rejected by local authorities. Concerns have also been raised on court rulings that compelled the health system and insurance companies to cover untested procedures, diverting resources that could be used for other ends. However, the issue on how stem cell technologies could in the future be made accessible for most of the population (an aspiration that is promoted by some scholars and policy makers (Greenwood et al., 2006) and become integrated into national health systems, has not yet entered the public discussion and remains unclear. STI policy follows - once again - a linear science-driven innovation model; 
placing the construction of social utility at the end of the range of concerns of scientific practices.

(d) State led regulatory control vs. deregulation demands. Argentina's ambitions of stem cell technology is clearly led by the state, in a co-production process that has involved biomedical scientists and STI authorities and aligned other heterogeneous actors around this issue, both at the level of capacity building and regulation formation. On the other end of the spectrum, there is no organized demand for deregulation. Rather, one witnesses diffused actors working within the grey spaces of the legislation.

Stem cell research, clinical testing, production and marketing in Argentina still appears to have a long way to go. The construction of this field as a desirable technological future has focused on R\&D promotion and the prevention of unproven treatments. But the possibilities of conducting Phase I-III clinical trials and marketing these therapies with a global reach would require a more comprehensive approach. At present, local regulatory, production, and financial capabilities still do not facilitate this process. At the same time, considering the pressing problems the country faces in terms of ensuring people's access to basic goods and services (food, water and sanitation, housing, energy, access to health services, quality education, communication infrastructure), it is by and large, debatable if it is the State that should provide for such an increased outlay. This opens a new discussion on what goes beyond stem cell $R \& D$, and beyond tracing a new national strategy (and aligning new elements) to build the utility of this technology - as a strategic technology and not only a research priority - beyond laboratory walls and with concrete social benefits. 
Gabriela Bortz holds a PhD in Social Sciences (Universidad de Buenos Aires), a postdoctoral fellowship from the National Council for Scientific and Technical Research (CONICET) at the Institute of Science and Technology Studies, Universidad Nacional de Quilmes (IESCTUNQ), Buenos Aires, Argentina.

$\triangleq$ gabybortz@gmail.com

Achim Rosemann holds a PhD in Social Anthropology (University of Sussex) and is currently an associate researcher in the Department of Sociology, Philosophy and Anthropology, University of Exeter, United Kingdom, UK.

Đa.rosemann@exeter.ac.uk

Federico Vasen holds a PhD in Social and Human Sciences (Universidad Nacional de Quilmes), is currently Assistant Researcher at CONICET and researcher at the Institute of Educational Sciences, School of Philosophy and Letters, University of Buenos Aires (UBA), Argentina.

Đ' federico.vasen@gmail.com 


\section{References}

1. AKRICH, Madeleine. The de-scription of technical objects. In: BIJKER, Wiebe; LAW, John (Org.). Shaping technology/building society. Studies in Sociotechnical Change. Cambridge: MIT Press, 1992, p. 205-24.

2. ANASTASIA, Luigi et al. Cell reprogramming: expectations and challenges for chemistry in stem cell biology and regenerative medicine. Cell Death \& Differentiation, v. 17, n. 8, 1230-7, 2010.

3. ARZUAGA, Fabiana. Cuestiones éticas y normativas de las investigaciones y terapias con células madre. Perspectivas Bioéticas, v. 19, n. 35-36, p. 79-88, 2014.

4. ARZUAGA, Fabiana. Stem cell research and therapies in Argentina: the legal and regulatory approach. Stem Cells Development, v. 22, n. 1, p. 40-3, 2013.

5. BIN ABDUL AZIZ, M. Firdaus; MORRISON, Michael; KAYE, Jane. Regulating human stem cell research and therapy in low- and middle-income countries: Malaysian perspectives. New Genetics and Society, v. 37, n. 1, p. 2-20, 2017. DOI: $10.1080 / 14636778.2017 .1415137$

6. BORTZ, Gabriela. Biotecnologías para el desarrollo inclusivo y sustentable. Políticas públicas y estrategias de producción de conocimiento, desarrollo tecnológico e innovación para resolver problemas sociales y ambientales en Argentina (2007-2016). (Dissertation. Doctorate in Social Sciences), Universidad de Buenos Aires, Argentina, 2017.

7. BORTZ, Gabriela; VASEN, Federico; ROSEMANN, Achim. Entre oportunidad y riesgo: regulación, expectativas y políticas $\mathrm{CTI}$ para células madre en Argentina. Ciencia, Docencia y Tecnología, v. 28, n. 54, p. 38-74, 2017.

8. BRAITHWAITE, John; COGLIANESE, Cary; and LEVI-FAUR, David. Can regulation and governance make a difference? Regulation \& Governance, v. 1, n. 1, p. 1-7, 2007.

9. CALLON, Michel. The dynamics of techno-economic networks. In: COOMBS, Rod; SAVIOTTI, Paolo; WALSH, Vivien (Orgs.). Technological change and company strategies. London: Harcourt Brace Jovanovich, 1992, p. 72-102.

10. CÉLULAS MADRE: BUSCAN REGULARLAS como remedios biológicos y frenar el vacío legal en el país. Clarín, Oct 19, 2018. Available at: <https:// www.clarin.com/sociedad/celulas-madre-buscan-regularlas-remedios-biologicosfrenar-vacio-legal-pais_0_1 N90qutE.html $>$.

11. COMISIÓN ASESORA EN TERAPIAS CELULARES Y MEDICINA REGENERATIVA [CATCMR-MCTIP]. Investigación y células madre: nociones para un debate necesario, 2009a. Available at: < http://www.celulasmadre. mincyt.gob.ar/Documentos/INVESTIGACION_Y_CELULAS_MADRE.pdf $>$.

12. COMISIÓN ASESORA EN TERAPIAS CELULARES Y MEDICINA REGENERATIVA [CATCMR-MCTIP]. Declaración acerca de la guarda de células madre de sangre de cordón umbilical, 2009b. Available at: <http://www. 
celulasmadre.mincyt.gob.ar/Documentos/DECLARACION_CELULAS_MADRE_ CORDON_UMBILICAL.pdf $>$.

13. COMISIÓN ASESORA EN TERAPIAS CELULARES Y MEDICINA REGENERATIVA [CATCMR-MCTIP]. Claves para el debate sobre células madre, 2009c. Retrieved from: <http://www.celulasmadre.mincyt.gob.ar/Documentos/ CLAVES_PARA_EL_DEBATE_SOBRE_CELULAS_MADRE.pdf $>$.

14. COMISIÓNASESORAENTERAPIAS CELULARESYMEDICINAREGENERATIVA [CATCMR-MCTIP]. Células madre: sólo existen dos tratamientos clínicamente aprobados, 2012. Retrieved from: <http://www.mincyt.gov.ar/noticias/noticias detalles.php?id_noticia $=787>$.

15. CONICET. Células madre: "Van a ser una revolución en medicina". CONICET [sítio web institucional], noticias, Oct. 12, 2012. Available at: <http://www. conicet.gov.ar/celulas-madre-van-a-ser-una-revolucion-en-medicina/ $>$.

16. DE SANTO, Yésica. Pacientes se unieron para alertar sobre las estafas con células madre. Tiempo Argentino, May 11, 2014.. Available at: < http://www. infonews.com/nota/143381/pacientes-se-unieron-para-alertar-sobre > .

17. FEDERACIÓN ARGENTINA DE ENFERMEDADES POCO FRECUENTES (FADEPOF). Florencia Braga Menéndez: presentation at Stem Cell Summit 2013 [video], Dec. 4-6, 2013. Available at: <http://fadepof.org.ar/videos/20>.

18. FEDERACIÓN ARGENTINA DE ENFERMEDADES POCO FRECUENTES (FADEPOF). Informe sobre ensayo clínico con células madres en pacientes con lesiones oculares, Nov. 2, 2014. Available at: <http://fadepof.org.ar/ noticias $/ 53>$.

19. FERRERAS, Andrés. Células madres: China ofrece en Córdoba los tratamientos. La Voz, May 29, 2012.. Available at: <https://www.lavoz.com.ar/ciudadanos/ celulas-madres-china-ofrece-cordoba-tratamientos $>$.

20. FUROR SOLIDARIO en las redes sociales por Helenita. Clarín, July 18, 2014. Available at: <http://www.clarin.com/sociedad/Furor-solidario-redes-socialesHelenita_0_1177082445.html>.

21. GARAU, Joaquín. Cuánto cuesta guardar células madre en la Argentina. Revista Apertura, June 10, 2015. Available at: < http://www.apertura.com/tecno/ Cuanto-cuesta-guardar-celulas-madre-en-la-Argentina-20150610-0003.html > .

22. GOTTWEIS, Herbert; MINGER, Stephen. iPS cells and the politics of promise. Nature Biotechnology, v. 26, n. 3, p. 271-2, 2008.

23. GOTTWEIS, Herbert; PRAINSACK, Barbara. Emotion in political discourse: contrasting approaches to stem cell governance in the USA, UK, Israel and Germany. Regenerative Medicine, v. 1, n. 6, p. 823-9, 2006.

24. GREENWOOD, Heather et al. Regenerative medicine and the developing world. PLoS Medicine, v. 3, n. 9, e381, 2006.

25. GRIPPO, Andrés. Células madre para curar la desesperanza. Materia, Nov. 8, 2013. Available at: <http://esmateria.com/2013/11/08/celulas-madre-para-curarla-desesperanza/?all=1>. 
26. GUARDAR CÉLULAS MADRE no es egoísmo sino protección biológica para hijos y familia. Clarín, Nov. 19, 2011. Available at: < http://www.clarin.com/ edicion-impresa/Guardar-egoismo-proteccion-biologica-familia_0_594540650. html $>$.

27. HARMON, Shawn; KALE, Dinar. Regulating in developing countries: multiple roles for medical research and products regulation in Argentina and India. Technology in Society, v. 43, p. 10-22, 2015.

28. HARTMAN, Irene. Células madre: un futuro clínico prometedor entre estafas y promesas engañosas. Clarín, Dec. 17, 2017.. Available at: <https://www. clarin.com/suplementos/zona/celulas-madre-futuro-clinico-prometedor-estafaspromesas-enganosas_0_S1MTxYbzf.html>.

29. JASANOFF, Sheila; KIM, Sang-Hyun. Containing the atom: sociotechnical imaginaries and nuclear power in the United States and South Korea. Minerva, v. 47, p. 119-46, 2009.

30. KRMPOTIC, Claudia. Creer en la cura. Eficacia simbólica y control social en las prácticas del Dr. M. Scripta Ethnologica, v. XXXIII, p. 97-116, 2011.

31. LAS PREPAGAS también deben costear los tratamientos con células madre. Diario Judicial, Jan. 19, 2011. Available at: < http://www.diariojudicial.com/ nota/27164>.

32. LASCOUMES, Pierre; LE GALES, Patrick. Introduction: Understanding public policy through its instruments. From the nature of instruments to the sociology of public policy Instrumentation. Governance, v. 20, n. 1, p. 1-21, 2007.

33. LEVÁNTENSE Y ANDEN. Página 12, Nov. 6, 2015. Available at: <http:// www.pagina12.com.ar/diario/sociedad/3-285563-2015-11-06.html>.

34. LUNA, Florencia; SALLES, Arleen. Investigación con células madre: el debate ético. Perspectivas Bioéticas, v. 19, n. 35-6, p. 47-52, 2014.

35. MATTIS, Virginia; SVENDSEN, Clive. Induced pluripotent stem cells: a new revolution for clinical neurology? The Lancet Neurology, v. 10, n. 4, p. 383-94, 2011.

36. MCMAHON, Dominique. The global industry for unproven stem cell interventions and stem cell tourism. Tissue Engineering and Regenerative Medicine, v. 11, n. 1, p. 1-9, 2014.

37. MCMAHON, Dominique; THORSTEINSDÓTTIR, Halla. Pursuing endogenous high-tech innovation in developing countries: a look at regenerative medicine innovation in Brazil, China and India. Research Policy, v. 42, n. 4, p. 965-74, 2013.

38. MIKAMI, Koichi. State-supported science and imaginary lock-in: the case of regenerative medicine in Japan. Science as Culture, v. 24, n. 2, p. 183-204, 2015.

39. MINISTERIO DE CIENCIA, TECNOLOGÍA E INNOVACIÓN PRODUCTIVA [MCTIP]. Se realizó la 2 da conferencia internacional sobre células madre. MCTIP [site institucional], noticias, Oct. 15, 2008. Retrieved from: < http://www. 
mincyt.gob.ar/noticias/se-realizo-la-2da-conferencia-internacional-sobre-celulasmadre-4191>

40. MINISTERIO DE CIENCIA, TECNOLOGÍA E INNOVACIÓN PRODUCTIVA $[\mathrm{MCTIP}]$. Plan nacional de ciencia, tecnología e innovación 2012-2015 (preliminary version). Buenos Aires: MCTIP, 2011.

41. MINISTERIO DE CIENCIA, TECNOLOGÍA E INNOVACIÓN PRODUCTIVA $[\mathrm{MCTIP}]$. Plan nacional de ciencia, tecnología e innovación "Argentina inovadora 2020". Buenos Aires: MCTIP, 2012.

42. MINISTERIO DE CIENCIA, TECNOLOGÍA E INNOVACIÓN PRODUCTIVA [MCTIP]. Crece el debate sobre las terapias avanzadas en la Argentina. MCTIP [site institucional], noticias, July 12, 2016.. Retrieved from: < http://www.mincyt.gob.ar/ noticias/crece-el-debate-sobre-las-terapias-avanzadas-en-la-argentina-12164>

43. PALMA, Verónica et al. Stem cell research in Latin America: update, challenges and opportunities in a priority research area. Regenerative Medicine, v. 10, n. 6, p. 785-98, 2015.

44. PÉREZ, Carlota. Technological change and opportunities for development as a moving target, Cepal Review, v. 75, p. 109-30, 2001.

45. PITOSSI, Fernando; PODHAJCER, Osvaldo. Current status of stem cells and regenerative medicine research in Argentina. Stem Cells and Development, v. 23, n. 1, p. 17-9, 2014.

46. RED DE INDICADORES DE CIENCIA Y TECNOLOGÍA (RICYT). El estado de la ciencia. Buenos Aires: RICYT, 2017.

47. RESEARCH AND MARKETS. Global Stem Cells Market Research Report 2018. Markets Insider, 2018. Available at: <https://markets.businessinsider.com/news/ stocks/global-stem-cells-market-research-report-2018-1027517832>.

48. ROSEMANN, Achim et al. Global regulatory developments for clinical stem cell research: diversification and challenges to collaborations. Regenerative Medicine, v. 11, n. 7, p. 647-57, 2016.

49. ROSEMANN, Achim; BORTZ, Gabriela; VASEN, Federico. Regulatory developments for nonhematopoietic stem cell therapeutics: perspectives from the EU, the USA, Japan, China, India, Argentina, and Brazil. In: CHEN, Xiao-Dong (Org.), A roadmap to non-hematopoietic stem cell-based therapeutics. From the bench to the clinic. Londres: Elsevier, 2018, p. 463-92.

50. ROSEMANN, Achim; VASEN, Federico; BORTZ, Gabriela. Global diversification in medicine regulation: insights from regenerative stem cell medicine. Science as Culture, 2018. Available at: < https://doi.org/10.1080/09 505431.2018.1556253>.

51. ROSEMANN, Achim; CHAISINTHOP, Nattaka. The pluralization of the international: resistance and alter-standardization in regenerative stem cell medicine. Social Studies of Science, v. 46, n. 1, p. 112-39, 2016.

52. SABATIER, Paul; WEIBLE, Christopher. The advocacy coalition framework. Theories of the policy process, v. 2, p. 189-220, 2007. 
53. SALTER, Brian; ZHOU, Yinhua; DATTA, Saheli. Hegemony in the marketplace of biomedical innovation: consumer demand and stem cell science. Soc Sci Med, v. 131, p. 156-63, 2015.

54. SALTER, Brian. Governing stem cell science in China and India: emerging economies and the global politics of innovation. New Genetics and Society, v. 27 , n. 2, p. 145-59, 2008.

55. SINGER, Emily. A STEM-CELL REVOLUTION. MIT Technology Review, 27 ago. 2008. Available at: <https://www.technologyreview.com/s/410750/a-stemcell-revolution/>.

56. SISTEMA DE INFORMACIÓN DE CIENCIA Y TECNOLOGÍA ARGENTINO (SICYTAR). Website institutional, 2018. Available at <http://sicytar.mincyt.gob. $\operatorname{ar} />$

57. SLEEBOOM-FAULKNER, Margaret et al. Comparing national home-keeping and the regulation of translational stem cell applications: an international perspective. Social Science \& Medicine, v. 153, p. 240-9, 2016.

58. SLEEBOOM-FAULKNER, Margaret; PATRA, Prasanna K. The bioethical vacuum: national policies on human embryonic stem cell research in India and China. Journal of International Biotechnology Law, v. 5, n. 6, p. 221-34, 2008.

59. STEKOLSCHIK, Gabriel. Las madres de la ilusión. Revista EXACTAmente, v. 14, n. 39, 2008. Available at: <http://www.fcen.uba.ar/fotovideo/EXm/PDF/ EXM39.pdf>.

60. THERBORN, Göran. La ideología del poder y el poder de la ideología. México: Siglo XXI, 1989.

61. THOMAS, Hernan; BECERRA, Lucas; GARRIDO, Santiago. Socio-technical dynamics of counter-hegemony and resistance. In: GODIN, Benoit; VINCK, Dominique (Orgs.) Critical studies of innovation: alternative approaches to the pro-innovation bias. Edward Elgar: UK-US, 2017, p. 182-200.

62. VASEN, Federico. Regulación tecnológica y valores sociales: un análisis del caso farmacéutico. Scientiae Studia, v. 6, n. 3, p. 409-26, 2008.

63. VISION GAIN. Global stem cell technologies and applications market 2018-2028, 2018. Available at: < https://www.visiongain.com/report/global-stemcell-technologies-and-applications-market-2018-2028/>

64. WEBSTER, Andrew; HADDAD, Christian; WALDBY, Catherine. Experimental heterogeneity and standardisation: stem cell products and the clinical trial process. BioSocieties, v. 6, n. 4, p. 401-19, 2011.

65. ZWANENBERG, Patrick van; ELY, Adrian; SMITH, Adrian. Regulating technology: international harmonization and local realities. Londres: Routledge, 2011.

Submitted: Nov 17, 2018

Accepted: Jan 8, 2019 